\title{
The role of perceived social support on social skills of students with special needs
}

\author{
Iftita Rahmi ${ }^{1}$ * \\ ${ }^{1}$ Politeknik Negeri Jakarta, 16425, Indonesia. \\ * Corresponding Author. E-mail: Iftita.rahmi@ akuntansi.pnj.ac.id, Phone: +6285263645409
}

\begin{abstract}
The purpose of this study was to discover the relationship between perceived social support from family and peers on the social skills of students with special needs. This study was conducted with postsecondary education students in a 3-year college $(\mathrm{N}=42)$ with various types of disability This study used a quantitative method with a correlational non-experimental approach. The results of this study indicated that perceived social support from family and friends affects the social skills of students with special needs. The form of social support associated with the social skills of special needs students is emotional and information support. The implications and possible applications of the relationship between social support and social skills among college students with special needs are discussed.
\end{abstract}

Keywords: perceived social support, social skills, students with special needs

\section{Peran dukungan sosial terhadap keterampilan sosial mahasiswa berkebutuhan khusus}

\begin{abstract}
Abstrak: Tujuan penelitian ini adalah untuk mengetahui hubungan antara persepsi dukungan sosial dari keluarga dan teman sebaya terhadap keterampilan sosial siswa berkebutuhan khusus. Penelitian ini dilakukan pada mahasiswa berkebutuhan khusus yang menempuh pendidikan vokasi/Diploma $3(\mathrm{~N}=42)$ dengan jenis disabilitias yang beragam. Penelitian ini menggunakan metode kuantitatif dengan pendekatan korelasional. Hasil penelitian ini menunjukkan bahwa persepsi terhadap dukungan sosial dari keluarga dan teman sebaya berpengaruh terhadap keterampilan sosial mahasiswa berkebutuhan khusus. Adapun bentuk dukungan sosial yang berpengaruh terhadap keterampilan sosial mahasiswa berkebutuhan khusus adalah dukungan dalam bentuk emosi dan informasi. Implikasi dan kemungkinan penerapan hubungan antara persepsi terhadap dukungan sosial dan keterampilan sosial pada mahasiswa berkebutuhan khusus dibahas dalam diskusi.
\end{abstract}

Kata Kunci: persepsi dukungan sosial; keterampilan sosial; mahasiswa berkebutuhan khusus

\section{INTRODUCTION}

In higher education, adjustment to the campus environment poses challenges for all students including students with special needs. The ability to manage accommodation and assignments is a challenge for students with special needs (Getzel \& Thoma, 2008). Besides, students with special needs also experience problems in social adjustment with their peers on campus. In a study conducted by Mclntyre and Phaneuf (2008), it was stated that children with special needs often experience behavioral problems because of underdeveloped social skills and/or the inability to use social skills that are already owned properly.

Social skills are essentials for students in higher education settings where students are required to be able to solve problems both individually and in collaboration and to express their opinions well. Shaffer (2009) states that social skills are thoughts, actions, and emotional regulation activities that allow a person to achieve personal and social goals while maintaining harmony with their social partners. Social skills are complex behaviors that result from learning which include the skills of expressing and receiving praise, expressing and receiving complaints, rejecting unreasonable requests, affirming individual rights, asking for help, proposing changes in other people's behavior, solving problems, hanging out with friends of the opposite sex, and socializing with older people (Michelson et al., 1983).

Based on the information above, social skills are important skills for a student not only when taking higher education, but also for getting a job later. The development of social skills is influenced 
by support from the surrounding environment such as family (Leano, 2015) and peers (Rodda \& Estes, 2018). For students with special needs, peers are an important element because they can be a place for social learning (Mathews et al., 2018). Interaction with peers can help individuals with special needs in developing social skills that are difficult to obtain in a non-authoritarian atmosphere (Shaffer, 2009).

Social support is helping individuals receive from other people or other groups around them that make the individual feel comfortable, cared for, loved, and appreciated (Sarafino \& Smith, 2011). Forms of support such as attention, care, empathy, and positive expressions from friends make a person feel comfortable and loved, and foster feelings of worth which then lead to a positive view of himself and his environment. Social support can be obtained from family, peers, spouses, coworkers, and even from social media (Cole et al., 2017; Lee \& Goldstein, 2016; Sullivan et al., 2020).

Family is the main source of social support for children with special needs. In research conducted by Mangunsong and Wahyuni (2018), it was found that parental involvement has a significant relationship with the social skills of children with special needs. Also, Sutoyo and Hendriani (2018) in their research on children with hearing impairment found that $96.6 \%$ of the social skills of children with special needs are influenced by family support and self-concept. However, as students spend more time with peers in college, peers become one of the important support groups for students with special needs. Peers become one of the strong predictors for special needs students' social adjustment (Dennis et al., 2005) and also support inclusive education by increasing acceptance, communication, and guiding students with special needs (Bond \& Castagnera, 2006).

Several factors affect social skills in students with special needs, namely gender, types of barriers, and different levels of barriers. Mangunsong and Wahyuni (2018) found that boys with special needs tend to have better social skills than girls. In contrast, a study conducted by Epley (2009) stated that children with special needs girls have better social skills than boys. Based on the type of obstacle, Lane et al. (2006) found that individuals who experience emotional disorders have lower social skills than children who experience learning difficulties. However, Macintosh and Dissanayake (2006) found that there was no difference in social skills between children with high functioning autism (HFA) and Asperger's Disorder. Based on the level of resistance, Bennett and Hay (2007) found that there was no difference in social skills among students with different levels of physical resistance.

The purpose of this study was to examine the relationship between social support perceived by special needs students and their social skills. There has been some research on peer and parent support and its relationship to the dimensions of social skills. Research conducted by Astarini et al. (2016) stated that there is a relationship between student's perceptions of parental and peer support on interpersonal communication skills. Lutfi (2012) in his research found that there was a positive and significant relationship between peer support and problem-solving abilities among students. But these researches did not measure the relation of social support and social skill in general, only with the dimensions of social skills. Most study about social support in Indonesian context, emphasize social support from the perspective of the one who gives the support (Fauzia \& Mangunsong, 2020; Kurniawati et al., 2018; Rosalina \& Apsari, 2020; Syahda \& Mazdarianti, 2018; Tanjung \& Iswari, 2019) or examine the social support for the caregivers/significant others of the special needs students (Albintary et al., 2018; Hidayati \& Sawitri, 2017; Putri et al., 2019). Yet, there is limited study in Indonesian context about the perception of students with special needs of social support given by family and peers, and its relation to their social skills.

\section{RESEARCH METHODS}

\section{Participants}

The participant of this study was 42 postsecondary education students age 18-24 years in a 3year college with various types of disability. All participants in this study had a mild level of resistance based on the AAMR Ad hoc on Terminology and Classification in Mangunsong (2009). Students with a mild level of resistance are students who need a little help in daily activities. See Table 1 for more specific information on participant characteristics. 
JPK (Jurnal Pendidikan Khusus), 17 (1), 2021 - 3

Iftita Rahmi

Table 1. Participants Characteristics $(N=42)$

\begin{tabular}{llcc}
\hline Demographic & & $N$ & \% \\
\hline Sex & Male & 31 & 73,8 \\
& Female & 11 & 26,2 \\
\hline Type of disability & Visual Impairment & 1 & 2,4 \\
& Hearing Impairment & 5 & 11,9 \\
& Physically Disable & 1 & 2,4 \\
& Intellectual Disabilities & 1 & 2,4 \\
& Slow Learner & 19 & 45,2 \\
& ASD* & 9 & 21,4 \\
& ADHD** & 5 & 11,9 \\
& More than 1 impairment & 1 & 2,4 \\
\hline
\end{tabular}

*Autism Spectrum Disorder

**Attention-Deficit/Hyperactivity Disorder

\section{Measures}

Perceived family social support

Perceived family social support scale used in this study developed by Hayati (2014) was developed from forms of social support according to Sarafino and Smith (2011), namely emotional support, real/instrumental support, information support, and companionship support. This scale consist of 50 items, has a reliability coefficient $\alpha=0.970$ and the total item correlation ranges from $r=0.289$ to $\mathrm{r}=0.822$. This scale uses the summated rating method or Likert scale, with four alternative answers, namely: Very Fit (SS), Suitable (S), Not Suitable (TS), and Very Unsuitable (STS). This scale was adapted to adjust the subject of this study. The adapted scale consists of 32 items, has a reliability coefficient $\alpha=0.909$ and the total item correlation ranges from $r=0.316$ to $r=0.672$.

Perceived peers social support

Perceived peer social support scale used in this study developed by Rejeki (2016) consists of 37 items. This scale was developed from the description of the forms of social support according to Sarafino and Smith (2011), namely emotional support, real/instrumental support, information support, and companionship support. This scale consist of 37 items, has a reliability coefficient $\alpha=0.954$ and the total item correlation ranges from $r=0.460$ to $r=0.763$. This scale uses the summated rating method or Likert scale, with four alternative answers, namely: Very Fit (SS), Suitable (S), Not Suitable (TS), and Very Unsuitable (STS). This scale was adapted to adjust the subject of this study. The adapted scale consist of 34 items, has a reliability coefficient $\alpha=0.940$ and the total item correlation ranges from $r=0.261$ to $r=0.763$.

Social skills

The scale to measure social skills used in this study was a scale developed by Ramdhani and Martaniah (1995) and modified by Nugraini and Ramdhani (2017). This scale consists of 24 items developed from aspects of social skills, namely verbal, nonverbal, and cognitive processes (Michelson et al., 1983). This scale consist of 24 items, has a reliability coefficient $\alpha=0.876$ and the total item correlation ranges from $r=0.287$ to $r=0.664$. This scale consists of five answer choices that allow you to approach the description of the subject start from very often (SS), often (S), sometimes (K), occasionally (SE), and never (TP). This scale was also adapted to adjust the subject of this study. The adapted scale consist of 15 items, has a reliability coefficient $\alpha=0.830$ and the total item correlation ranges from $r=0.373$ to $r=0.637$.

\section{Procedure}

The scales used in this study were digitized to be disseminated through links to the participants. To some of the participants, the scales were applied individually via online video conference. The questions were read by the researcher and the students were asked if they understood the question or not and if there is any part they could not understand, the researcher will explain further in detail. Each 
application lasted for 30-40 minutes on average and the answers were recorded to the relevant form by the researcher.

\section{Data Analysis}

Data analysis was carried out via SPSS package software version 22.0. Analysis of the data was used correlation, linear regression, and independent t-test. Correlation was used to determine the correlation between social support perceived by students with special needs and their social skills. Multiple linear regression tests to determine the effect of perceived social support from family and peers on social skills of students with special needs, and an independent t-test to determine differences in social skills between male and female students with special needs.

\section{RESULTS AND DISCUSSION}

This section will explain the results of the study consisted of descriptive statistics of each variable (Table 2, 3, 4, and 5), the correlation between the dimensions of the variables (Table 6 and 7), and the factors that influence the social skills of students with special needs.

Based on Tables 3 and 4, the mean score of perceived social support given by family and peers which is divided into emotional, informational, real, and companionship support is above the midpoint value of the scale. These results indicate that students with special needs have a perception that the support of their parents and peers tends to be high. It can be said that students with special needs perceive and feel that their parents and peers are parties who can be relied on in providing enthusiasm, assistance, acceptance, and attention in their daily activities.

Table 2. Descriptive statistics $(N=42)$

\begin{tabular}{lllll}
\hline Variable & Mean & SD & Minimum & Maximum \\
\hline Perceived family support & 95.83 & 10.961 & 74 & 122 \\
Perceived peers support & 115.45 & 15.026 & 83 & 148 \\
Social skills & 75.93 & 11.143 & 53 & 100 \\
\hline
\end{tabular}

Table 3. Descriptive statistics of perceived family support $(N=42)$

\begin{tabular}{lllll}
\hline $\begin{array}{l}\text { The dimensions of perceived } \\
\text { family support }\end{array}$ & Mean & SD & Minimum & Maximum \\
\hline Emotional support & 3,18 & 0,72 & 1 & 4 \\
Information support & 2,75 & 0,93 & 1 & 4 \\
Real support & 3,03 & 0,85 & 1 & 4 \\
Companionship support & 3,02 & 0,86 & 1 & 4 \\
\hline
\end{tabular}

Table 4. Descriptive statistics of perceived peer support ( $N=42)$

\begin{tabular}{lllll}
\hline $\begin{array}{l}\text { The dimensions of perceived } \\
\text { peer support }\end{array}$ & Mean & SD & Minimum & Maximum \\
\hline Emotional support & 3,13 & 0,70 & 1 & 4 \\
Information support & 3,14 & 0,77 & 1 & 4 \\
Real support & 3,01 & 0,81 & 1 & 4 \\
Companionship support & 3,13 & 0,75 & 1 & 4 \\
\hline
\end{tabular}

Table 5. Descriptive statistics of social skills $(N=42)$

\begin{tabular}{lllll}
\hline The dimensions of social skills & Mean & SD & Minimum & Maximum \\
\hline Verbal & 3,22 & 1,26 & 1 & 5 \\
Nonverbal & 3,14 & 1,34 & 1 & 5 \\
Cognitive & 3,13 & 1,20 & 1 & 5 \\
\hline
\end{tabular}


Based on Table 5, the average score of social skills perceived by students with special needs is above the midpoint on the three aspects of social skills, namely verbal, nonverbal, and cognitive responses. This shows that in general, students with special needs consider themselves to have high social skills, both in responding verbally, nonverbally and in processing information from the environment.

Table 6. Correlation between perceived family support and social skills

\begin{tabular}{llccccc}
\hline \multirow{2}{*}{ Variable } & \multicolumn{5}{c}{ Perceived family support } \\
\cline { 2 - 7 } & All & All & Emotional & Information & Real & Companionship \\
\hline \multirow{3}{*}{ Social } & Verbal & $.329^{*}$ & $.341^{*}$ & $.416^{* *}$ & .249 & .125 \\
skills & .086 & .150 & .234 & .059 & -.090 \\
& Nonverbal & $.335^{*}$ & .290 & $.339^{*}$ & .285 & .194 \\
& Cognitive & $.484^{* *}$ & $.478^{* *}$ & $.527^{* *}$ & $.340^{*}$ & .283 \\
\hline
\end{tabular}

*significant at 1.o.s 0,05 (2-tailed)

** significant at 1.o.s 0,01(2-tailed)

Results of the correlation test showed that there is a significant correlation between the score of student's social skills and students ' perceived social support given by the family in general $(\mathrm{r}=0.329$; $\mathrm{p}>0.05)$. Still, among all forms of support, only emotional support $(r=0.341 ; p>0.05)$ dan informational support $(\mathrm{r}=0.416 ; \mathrm{p}>0.01)$ have a significant correlation with social skills in general.

Table 7. Correlation between perceived peer support and social skills

\begin{tabular}{lllcccc}
\hline \multirow{2}{*}{ Variable } & \multicolumn{5}{c}{ Perceived family support } \\
\cline { 3 - 7 } & All & All & Emotional & Information & Real & Companionship \\
\hline \multirow{3}{*}{ Social } & Verbal & .247 & $.304^{*}$ & $.330^{*}$ & .097 & .186 \\
skills & .149 & .188 & .248 & .059 & .077 \\
& Nonverbal & .193 & .236 & .275 & .072 & .139 \\
& Cognitive & $.308^{*}$ & $.377^{*}$ & $.324^{*}$ & .125 & .288 \\
\hline
\end{tabular}

*significant at l.o.s 0,05 (2-tailed)

** significant at 1.o.s 0,01(2-tailed)

Results of the correlation test showed that there is no significant correlation between the scores of social skills with peer support in general $(r=0.247 ; p>0.05)$. However, social skills have a positive correlation with peer support in the form of emotional $(r=0.304 ; p<0.05)$ and information $(r=0.330$; $\mathrm{p}<0.05)$.

Researchers conducted multiple linear regression tests to determine the effect of perceived social support from family and peers on social skills of students with special needs, and an independent t-test to determine differences in social skills between male and female students with special needs. Based on the multiple linear regression test, perceived family support and peer support together have a significant effect on the social skills of students with special needs $(F=4.016 ; \mathrm{p}$ $<0.05$ ). The magnitude of the influence given by the perception variable of family and peer social support is $12.6 \%$. This means that $12.6 \%$ of social skills can be explained by the variables of family support and peer support together, while $87.3 \%$ can be explained by other variables. Based on the results of the independent t-test, there was no difference in social skills scores between boys and girls with special needs $(\mathrm{t}=-1.57 ; \mathrm{p}>0.05)$.

The results of the study found that students with special needs perceptions of social support from family and friends tend to be high, all in the form of emotional, informational, instrumental, and companionship support. This result indicates that students with special needs assume that family and friends are reliable parties and can provide the encouragement, assistance, and attention they need. Family and peers are a significant source of support for students with special needs to be able to develop their potential. A previous study by McDonnall et al. (2012) stated that students with special needs need optimal support to improve their academic abilities and behavior. In addition, a study by Pinto et al. (2019) found that meaningful social contact with peers may improve social involvement 
and academic outcomes of students with special needs. Another study by Syahda and Mazdarianti (2018) found that family support is positively correlated with the autonomy of special needs students.

This study found that perceived social support from family has a positive correlation with the social skills of students with special needs. The data suggest that the more support special needs students received from their families, the better their social skills will be. This is in line with research conducted by Mangunsong and Wahyuni (2018) which states that parental involvement is positively correlated with the social skills of students with special needs. Similarly, Bennett and Hay (2007) also found that healthy family relationship makes greater development of children's social skill. Correspondingly, Demaray and Malecki (2002) found there is a significant positive relationship between perceived social support and a variety of positive indicators such as social skills, self-concept, and adaptive skills. The form of social support that has a positive correlation with the social skills of students with special needs is emotional support and information from parents. This is in line with research conducted by Riley et al. (2017) which states that children who get emotional support and autonomy show increased social skills, especially related to self-control. This finding is important for a family with special needs child's because even though their Childs become college students, they still need to increase their social skills, and family is one of the most important supporters for college students with special needs to learn and improve their social skills.

Family with special needs children can provide emotional support by showing empathy, care, and concern toward children to provide a feeling of comfort, peace, and being loved. This form of supports makes children feel valued, accepted, and cared for (Sarafino \& Smith, 2011). As for information support, family can provide advice, guidance, suggestions, or feedback about what has been done. Through interactions with others, individuals will be able to evaluate and reinforce their beliefs by comparing the opinions, attitudes, beliefs, and behaviors of others (Sarafino \& Smith, 2011). This support helps individuals overcome problems by broadening their knowledge and understanding of the problems. This information is needed to make decisions and solve problems practically as stated in the result of this study that information support from family has a positive correlation with the cognitive aspect of social skills.

Although this study demonstrates that there is no correlation between the perception of special needs students of social support from peers and their social skills in general, emotional and informational support from peers has a positive and significant correlation with the social skills of students with special needs. This result indicates students with special needs need to feel valued, accepted, and cared for by their peers. Peers could also help students with special needs in solving problems and making a decision. This result supports the claims of Pickens-cantrell (2016) that social support from peers helps students with special needs increase their social interaction. In another study, Estell and Perdue (2013) found that peer support is associated with a higher level of social skills especially emotional engagement with others. A study by Hasan and Handayani (2014) stated that social support from peers has a significant correlation with social adjustment in inclusive education settings. This finding is important for counselor and educational practitioner in college who provides education for students with special needs. College can arrange peer-mediated social skills training program for students with special needs as training with peers make students with special need feel fewer barriers than training with adult or older trainer (Chung et al., 2007). Special needs student struggles to interact with their peers, whether typically developing peers or special needs peers. Practicing certain social skill with peers, help student with special needs improve their social skill especially for social initiation and turn-taking (Harper et al., 2008).

Family support and peer support together have a significant effect on the social skills of students with special needs $(\mathrm{F}=4.016 ; \mathrm{p}<0.05)$. The magnitude of the influence given by the perception variable of family and peer social support is $12.6 \%$. This means that $12.6 \%$ of social skills can be explained by the variables of family support and peer support together, while $87.3 \%$ can be explained by other variables. $12.6 \%$ is a small, but significant impact number. Other factors can affect the social skills of students with special needs, including personality traits, social attainment (Eisler \& Fredericsen, 1980), educational, and environmental factors (Beauchamp \& Anderson, 2010; Bierman et al., 2010). The age of participants is relatively mature and is sufficiently able to take care of themselves. Therefore, although support from family and peers has a significant effect on social skills, the educational factor may have more influence on the development of social skills. 
The demographic factor tested in this study was only sex. The result demonstrates that there was no difference in social skills scores between male and female students in this study. This result contradicts the claim of Mangunsong and Wahyuni (2018) that male students tend to show significantly higher social skills than female students. Yet, a study by Epley (2009) revealed that girls tend to have better social skills than boys. The results in this study could be because the number of participants in this study was not as much as in the two previous studies.

The results of this study cannot be separated from several limitations. First, data on social support and social skills in this study were obtained from the perspective of students with special needs themselves. The results of the study might be different if other informants such as parents and lecturers were also included in the study. The researcher did not include socioeconomic factors as a variable in conducting the regression analysis, even though students with special needs with high socioeconomic status tended to have wider access to social and educational support than students with low socioeconomic status (Hefner \& Eisenberg, 2009; Malecki \& Demaray, 2006). Besides, participants in this study were students from the same institution who were exclusively educated for students with special needs. In general, the peers of the participants are also students with special needs who also need social support. This may affect the social support factor from peers where peers have not been able to provide the needed social support.

For further studies, researchers can obtain data on social support from the point of view of those who provide support such as lecturers, friends, and parents, as well as data on social skills assessed by parents or lecturers who frequently interact with participants. Also, researchers can add socioeconomic status and level of resistance as a factor in conducting regression tests on students' social skills. Moreover, researchers could also increase the number of participants to reduces the risk of accidentally having extreme, or biased participants.

\section{CONCLUSION}

The results showed that the perceived social support given by family and peers has a significant relationship with students' social skills. For students with special needs, social support provided by their families and peers is related to the social skills they need in adapting to the college environment. The results of this study indicate that parental support, peers support, and student's social skills are aspects that must be considered and improved in the context of education for an individual with special needs. Additionally, this research can be a foundation for parents, peers, counselors, and educators to continue to provide support in the form of emotional, information, real/instrumental, companionship to students with needs because they have greater challenges in facing academic life, especially in college.

\section{REFERENCES}

Albintary, R., Rahmawati, H., \& Tantiani, F. F. (2018). Dukungan Sosial Dan Parenting Self-Efficacy Pada Orang Tua Anak Autism Spectrum Disorder Di Kota Blitar. Jurnal Penelitian Dan Pengukuran Psikologi, 7(1), 46-52. https://doi.org/10.21009/jppp.071.06

Astarini, D., Nirwana, H., \& Ahmad, R. (2016). Hubungan antara Konsep Diri Sosial, Persepsi Siswa tentang Dukungan Sosial Orangtua, dan Teman Sebaya dengan Komunikasi Interpersonal Siswa dan Implikasinya terhadap Pelayanan Bimbingan dan Konseli. Konselor, 5(4), 247. https://doi.org/10.24036/02016546558-0-00

Beauchamp, M. H., \& Anderson, V. (2010). SOCIAL: an integrative framework for the development of social skills. Psychological Bulletin, 136(1), 39.

Bennett, K. S., \& Hay, D. A. (2007). The role of family in the development of social skills in children with physical disabilities. International Journal of Disability, Development and Education, 54(4), 381-397. https://doi.org/10.1080/10349120701654555

Bierman, K. L., Torres, M. M., \& Schofield, H. L. T. (2010). Developmental factors related to the assessment of social skills. In Practitioner's guide to empirically based measures of social skills (pp. 119-134). Springer. https://www.researchgate.net/profile/Lauren- 
Holleb/publication/251224552_Defining_Competence_and_Identifying_Target_Skills/links/004 6353cd73b87788e000000/Defining-Competence-and-Identifying-Target-Skills.pdf\#page=133

Bond, R., \& Castagnera, E. (2006). Peer support and inclusive education: An underutilized resource. $\begin{array}{llll}\text { Theory into } & \text { Practice, 24-229. }\end{array}$ https://doi.org/https://doi.org/10.1207/s15430421tip4503_4

Chung, K. M., Reavis, S., Mosconi, M., Drewry, J., Matthews, T., \& Tassé, M. J. (2007). Peermediated social skills training program for young children with high-functioning autism. Research in Developmental Disabilities, 28(4), 423-436. https://doi.org/10.1016/j.ridd.2006.05.002

Cole, D. A., Nick, E. A., Zelkowitz, R. L., Roeder, K. M., \& Spinelli, T. (2017). Online social support for young people: Does it recapitulate in-person social support; can it help? Computers in Human Behavior, 68, 456-464. https://doi.org/10.1016/j.chb.2016.11.058

Demaray, M. K., \& Malecki, C. K. (2002). Critical levels of perceived social support associated with student adjustment. School Psychology Quarterly, 17(3), 213-241. https://doi.org/10.1521/scpq.17.3.213.20883

Dennis, J. M., Phinney, J. S., \& Chuateco, L. I. (2005). The role of motivation, parental support, and peer support in the academic success of ethnic minority first-generation college students. Journal of College Student Development, 46(3), 223-236. https://doi.org/10.1353/csd.2005.0023

Eisler, R. M., \& Fredericsen, L. W. (1980). Perfecting Social Skills: A Guide to Interpersonal Behavior Development. Plenum Press. https://doi.org/10.1 007/978-1-4613-3186-5

Epley, P. H. (2009). Early school performance for students with disabilities: Examining the impact of early childhood special education, parent involvement, and family quality of life. (Unpublished Dissertation). Rockhurst University, Kansas.

Estell, D. B., \& Perdue, N. H. (2013). Social support and behavioral and affective school engagement: The effects of peers, parents, and teachers. Psychology in the Schools, 50(4), 325-339.

Fauzia, J. H., \& Mangunsong, F. M. (2020). The Effect of Social Support on the Social-Emotional Ability of Children with Special Needs Mediated by Parental Acceptance of Children. Psychology and Education, 57(4), 280-284.

Getzel, E. E., \& Thoma, C. A. (2008). Experiences of College Students With Disabilities and the Importance of Self-Determination in Higher Education Settings. Career Development for Exceptional Individuals, 31(2), 77-84. https://doi.org/10.1177/0885728808317658

Harper, C. B., Symon, J. B. G., \& Frea, W. D. (2008). Recess is time-in: Using peers to improve social skills of children with autism. Journal of Autism and Developmental Disorders, 38(815-826).

Hasan, S. A., \& Handayani, M. M. (2014). Hubungan antara Dukungan Sosial Teman Sebaya dengan Penyesuaian Diri Siswa Tunarungu di Sekolah Inklusi. Jurnal Psikologi Perkembangan Dan Pendidikan, 3(2), 128-135.

Hayati, L. (2014). Menonton Televisi Dan Bermain Video Games Sebagai Faktor Risiko Ganggguan Pemusatan Perhatian / Hiperaktivitas Pada Anak. Universitas Gadjah Mada, Yogyakarta.

Hefner, J., \& Eisenberg, D. (2009). Social support and mental health among college students. American Journal of Orthopsychiatry, 79(4), 491-499.

Hidayati, Z. K., \& Sawitri, D. R. (2017). Hubungan Antara Dukungan Sosial Dengan Maternal SelfEfficacy Pada Anak Autism Spectrum Disorder (Asd). Empati, 6(2), 10-14.

Kurniawati, Y., Faizah, F., \& Rahma, U. (2018). Dukungan Sosial Dan Empati Pada Siswa Berkebutuhan Khusus Berdasar Jenjang Sekolah Menengah Dan Perguruan Tinggi. Insight: Jurnal Pemikiran Dan Penelitian Psikologi, 14(2), 200. https://doi.org/10.32528/ins.v14i2.1393 


\section{JPK (Jurnal Pendidikan Khusus), 17 (1), 2021 - 9 \\ Iftita Rahmi}

Lane, K. L., Carter, E. W., Pierson, M. P., \& Glaeser, B. C. (2006). Academic, social, and behavioral characteristics of high school students with emotional disturbances or learning disabilities. Journal of Emotional and Behavioral Disorders, 14(2), 108-117.

Leano, A. J. (2015). Degree of parental support and level of adaptive skills of children with mental retardation. Research Journal of Educational Sciences, 3(9), 1-7.

Lee, C.-Y. S., \& Goldstein, S. E. (2016). Loneliness, Stress, and Social Support in Young Adulthood: Does the Source of Support Matter? Journal of Youth and Adolescence, 45(3), 568-580. https://doi.org/10.1007/s10964-015-0395-9

Lutfi, D. N. (2012). Hubungan antara dukungan teman sebaya dengan kemampuan pemecahan masalah pada santriwati pengurus organisasi pelajar ppmi assalaam. (Doctoral dissertation). Universitas Muhammadiyah Surakarta.

Macintosh, K., \& Dissanayake, C. (2006). Social skills and problem behaviours in school aged children with high-functioning autism and Asperger's disorder. Journal of Autism and Developmental Disorders, 36(8), 1065-1076. https://doi.org/10.1007/s10803-006-0139-5

Malecki, C. K., \& Demaray, M. K. (2006). Social Support as a Buffer in the Relationship between Socioeconomic Status and Academic Performance. School Psychology Quarterly, 21(4), 375395. https://doi.org/10.1037/h0084129

Mangunsong, F. (2009). Psikologi dan Pendidikan Anak Berkebutuhan Khusus, Jilid Kesatu. LPSP3 UI.

Mangunsong, F. M., \& Wahyuni, C. (2018). Keterlibatan Orang Tua terhadap Keterampilan Sosial Siswa Berkebutuhan Khusus di Sekolah Dasar Inklusif. Jurnal Psikologi, 45(3), 167. https://doi.org/10.22146/jpsi.32341

Mathews, T. L., Vatland, C., Lugo, A. M., Koenig, E. A., \& Gilroy, S. P. (2018). Training peer models to promote social skills: considerations for practice. Focus on Autism and Other Developmental Disabilities, 33, 160-170.

McDonnall, M. C., Cavenaugh, B. S., \& Giesen, M. J. (2012). The relationship between parental involvement and mathematics achievement for students with visual impairments. Journal of Special Education, 45(4), 204-215.

Mclntyre, L. L., \& Phaneuf, L. K. (2008). A three-tier model of parent education in early childhood. Topics in Early Childhood Special Education, 27(4), 214-222. https://doi.org/10.1177/0271121407311239

Michelson, L., Sugai, D. P., Wood, R. P., \& Kazdin, A. E. (1983). Social Skills Assessment and Training with Children. Springer Science + Business Media. https://doi.org/10.1017/CBO9781107415324.004

Nugraini, I., \& Ramdhani, N. (2017). Keterampilan Sosial Menjaga Kesejahteraan Psikologis Pengguna Internet. Jurnal Psikologi, 43(3), 183. https://doi.org/10.22146/jpsi.22139

Pickens-cantrell, C. (2016). The effectiveness of peer support to increase positive social interaction for $\begin{array}{lllll}\text { students with } & \text { special } & \text { needs. }\end{array}$ https://opus.govst.edu/cgi/viewcontent.cgi?article=1192\&context=capstones

Pinto, C., Baines, E., \& Bakopoulou, I. (2019). The peer relations of pupils with special educational needs in mainstream primary schools: The importance of meaningful contact and interaction with peers. British Journal of Educational Psychology, 89(4), 818-837. https://doi.org/10.1111/bjep.12262

Putri, S. S., Supena, A., \& Yatimah, D. (2019). Dukungan sosial orangtua anak tunarungu usia 11 tahun di SDN Perwira Kota Bogor. Jurnal EDUCATIO: Jurnal Pendidikan Indonesia, 5(1), 20. https://doi.org/10.29210/120192318 


\section{JPK (Jurnal Pendidikan Khusus), 17 (1), 2021 - 10 \\ Iftita Rahmi}

Ramdhani, N., \& Martaniah, S. M. (1995). Pelatihan keterampilan sosial pada mahasiswa yang sulit bergaul $=$ Social skills training on shy-socially isolated students. Berkala Penelitian Pasca Sarjana, 8(1995).

Rejeki, K. (2016). Strategi koping adaptif sebagai mediator hubungan antara persepsi dukungan sosial teman sebaya terhadap penyesuaian psikososial remaja saudara kandung penyandang disabilitas intelektual. (Unpublished thesis). Fakultas Psikologi, Universitas Gadjah Mada.

Riley, A., Anderson-Butcher, D., Logan, J., Newman, T. J., \& Davis, J. (2017). Staff practices and social skill outcomes in a sport-based youth Program. Journal of Applied Sport Psychology, 29(1), 59-74. https://doi.org/https://doi.org/10.1080/10413200.2016.1179700

Rodda, A., \& Estes, A. (2018). Beyond social skills: Supporting peer relationships and friendships for school-aged children with autism spectrum disorder. Seminars in Speech and Language, 39(2), 178-194. https://doi.org/https://doi.org/10.1055/s-0038-1628369

Rosalina, T. A., \& Apsari, N. C. (2020). Dukungan Sosial Bagi Orang Dengan Disabilitas Netra Dalam Pencapaian Prestasi Di Sekolah Luar Biasa. Prosiding Penelitian Dan Pengabdian Kepada Masyarakat, 7(2), 414. https://doi.org/10.24198/jppm.v7i2.28486

Sarafino, E. P., \& Smith, T. W. (2011). Health psychology: Biopsychosocial interaction (7th ed.). John Wiley \& Sons, Inc.

Shaffer, D. R. (2009). Social and personality development (6th ed.). Wadsworth, Cengage Learning.

Sullivan, L., Ding, K., Tattersall, H., \& Yang, J. (2020). Source of social support and post-injury depression and anxiety among college student-athletes.

Sutoyo, L. P. R., \& Hendriani, W. (2018). Peran Dukungan Keluarga dan Konsep Diri Terhadap Peningkatan Keterampilan Sosial Anak Tunarungu di Sekolah Inklusif. PHILANTHROPY: Journal of Psychology, 2(1), 37. https://doi.org/10.26623/philanthropy.v2i1.1139

Syahda, S., \& Mazdarianti. (2018). Hubungan Dukungan Keluarga Terhadap Kemandirian Anak Retardasi Mental Di Sdlb Bangkinang Tahun 2016. Jurnal Basicedu, 2(1), 43-48. https://doi.org/10.31004/basicedu.v2i1.25

Tanjung, B. S., \& Iswari, M. (2019). Dukungan orangtua terhadap prestasi anak tunanetra di sekolah inklusi. Jurnal Penelitian Pendidikan Kebutuhan Khusus, 7, 73-77.

\section{ACKNOWLEDGEMENT}

This research has been presented as a video presentation in the Virtual Conference 2020: "Psychology from a Cross-Cultural Perspective", on November $11^{\text {th, }} 2020$ co-organized by Universitas Indonesia and Maastricht University. The authors have declared that there are no potential conflicts of interest to the research, authorship, and/or publication of this article.

The authors would like to thank the Department Marketing Management for Student with Special Need, Politeknik Negeri Jakarta, and Unit of Research and Community Service Politeknik Negeri Jakarta. This work was supported by a grant from Unit of Research and Community Service (UP2M) Politeknik Negeri Jakarta [B202/PL3.18.PN.00.03/2019].

\section{PROFILE}

Iftita Rahmi was born on January 1st, 1991. She was graduated from Faculty of Psychology Universitas Indonesia and continue her master's degree in Faculty of Psychology Universitas Gadjah Mada. She works as a lecturer at Department of Marketing Manajemen for Student with Special Needs, Politeknik Negeri Jakarta. 